Open Access

\title{
Vegetative Compatibility Groups and Virulence Variation Among Isolates of Pyrenophora graminea
}

\author{
Mohammad Imad Eddin Arabi* and Mohammad Jawhar \\ Department of Molecular Biology and Biotechnology, AECS, P. O. Box 6091, Damascus, Syria \\ (Received on October 27, 2010; Accepted on April 5, 2011)
}

\begin{abstract}
Pyrenophora graminea, the causal agent of leaf stripe disease, is an economically important pathogen of barley found worldwide. Forty-four isolates of diverse geographical origin within Syria were grouped into vegetative compatibility groups (VCGs) by demonstrating heterokaryosis by complementation tests using nitrate nonutilizing (nit) mutants. All isolates were grouped into three VCGs-1-A, 1-B and 1-C. No self-incompatibility was observed in any of the isolates tested. VCG 1-A was the most common group within growing regions in Syria and proved to be the most virulent of the VCGs identified. These data indicate that the level of virulence in $P$. graminea is related to VCG.
\end{abstract}

Keywords : genetic diversity, mycelial compatibility group, nit mutants, Pyrenophora graminea

Pyrenophora graminea [anamorph Drechslera graminea (Rabenh. ex Schltdl.) Ito] the causal agent of leaf stripe, is an important pathogen of barley (Hordeum vulgare L.) found worldwide. This pathogen is considered economically important because it can cause marked reduction in yield and quality of the crop (Arabi et al., 2004; Porta-Puglia et al., 1986). The fungus is well known for its variable morphological and physiological traits (Arabi et al., 2005; 2006; Gatti et al., 1992; Jawhar et al., 2000). However, although efforts for developing and introducing leaf stripe resistant germplasms are under progress, these efforts have been impeded due to the lack of information about the fungal pathogen and the genetic structure of pathogen population.

Vegetative compatibility groups (VCG) is a genetically determined ability in which isolates of the same fungal species anastomose and form stable heterokaryons, during which genetic material may transfer from one isolate to another (Leslie, 1993). Isolates belonging to a VCG tend to have a common genetic pool (Leslie, 1993) and, therefore,

\footnotetext{
*Corresponding author.

Phone) +963-11-2132580, FAX) +963-11-6112289

E-mail)scientific@aec.org.sy
}

may have similar pathological and physiological traits differing from those of isolates that do not belong to that VCG (Day, 1974; Leslie, 1993; Nitzan et al., 2002).

Analysis of VCG has been used as a powerful method to classify races (Larkin et al., 1990; Wasilwa et al., 1993) for assessing genetic relationship among fungal populations (Grubisha and Cotty, 2010; Nitzan et al., 2002), and estimating the virulence level or host specificity of the isolates (Cherrab et al., 2002; Kauserud, 2004). Testing isolates for VCGs usually is based on complementation tests with nitrate-nonutilizing (nit) mutants, which are impaired in their ability to utilize nitrate from the growing media (Korolev et al., 2000; Nitzan et al., 2006).

Various DNA markers based polymerase chain reaction methods have been utilized to characterize Pyrenophora species. However, the use of VCGs has not yet been applied to the study of $P$. graminea genetic population, and no information is available on the relationship between VCG and virulence of its isolates on barley. The aims of this study were 1) to investigate the genetic diversity in the respect of VCG, and 2) to determine the relationship between VCG and virulence of $P$. graminea isolates pathogenic on barley.

\section{Materials and Methods}

Fungal isolates. Barley leaf tissues naturally infected with P. graminea were randomly sampled during 2002 and 2006. Leaf tissues with necrotic lesions were cut into pieces $(5 \times 10 \mathrm{~mm})$ and sterilized in $5 \%$ sodium hypochlorite ( $\mathrm{NaOCl}$ ) for $5 \mathrm{~min}$. After three washings with sterile distilled water, the pieces were transferred onto Petri dishes containing potato dextrose agar (PDA, DIFCO, Detroit, MI. USA) with $13 \mathrm{mg} / \mathrm{l} \mathrm{kanamycin} \mathrm{sulphate} \mathrm{added} \mathrm{after} \mathrm{auto-}$ claving and incubated for 10 days, at $21 \pm 1{ }^{\circ} \mathrm{C}$ in the dark to allow mycelial growth and sporulation. In preliminary studies (Arabi et al., 2004; 2006), 44 monosporic isolates were selected based on morphological and physiological criteria (virulence) for this study. Fungal isolates were cultured on potato dextrose agar (PDA, DIFCO, Detroit, MI USA) and incubated for 10 days at $22 \pm 1{ }^{\circ} \mathrm{C}$ in the dark. 
Virulence tests. Virulence tests of all isolates were performed on a universal susceptible cultivar 'Arrivate' from USA, using the method described by Hammouda (1986). Seeds were surface sterilized in $5 \% \mathrm{NaOCl}$ for $5 \mathrm{~min}$, washed several times in sterile deionized water, and left to dry between sterilized filter papers. They transferred into Petri dishes containing an actively growing mycelium (8 day-old) cultured on PDA media and incubated at $6{ }^{\circ} \mathrm{C}$ for 14 days in the dark. The control seeds were placed on PDA dishes without mycelium. After inoculation the seeds were removed carefully and planted in the field. Incidence and severity were estimated visually at the heading stage (Zadoks et al., 1974); Incidence was recorded as the proportion of diseased plants (number of plants with nonzero severity divided by the total number of plants sampled). Whereas, severity was recorded as infected leaf area per plant expressed as a proportion of the total area. No plants showing leaf stripe symptoms were found among the un-inoculated controls. The experiment was repeated twice. The mean of disease severity was first calculated for each isolate separately, and the mean values for each VCG and correlations were calculated using Student-Newman-Keuls test (Anonymous, 1988).

Vegetative compatibility. Nitrate nonutilizing (nit) mutants were generated and the phenotypes of all nit mutants were determined by the method of Correll et al. (1987). Stable nit1 and NitM phenotypes from each isolates were stored in the sterile distilled water at $4{ }^{\circ} \mathrm{C}$. Before complementation tests among isolates, vegetative self-incompatibility of each isolate was examined (Jacobson and Gordon, 1988). nit1 and NitM mutants of all 44 isolates of $P$. graminea were then paired in all possible combinations on minimal media (MM) (Puhalla, 1985) and the plates were incubated at $22^{\circ} \mathrm{C}$ in the dark. Vegetative compatible isolates were recognized by the robust growth at the interface of the two colonies about 12 days after inoculation.

\section{Results and Discussion}

All 44 isolates of $P$. graminea produced chlorate-resistant sectors on chlorate medium and phenotype ratio of nit mutants varied among them. Two to 10 nit mutants were obtained from each isolate of $P$. graminea. A total of $93 \mathrm{Nit}$ mutants were obtained from the 44 isolates.

Two phenotypic classes of nit mutants were identified, the nit (nit1/nit3) phenotype was recovered $(53.76 \%)$ and NitM was (46.24\%) (Table 1). Similar recovery frequencies of nit 1 and NitM classes also found for Fusarium oxysporum (Ahn et al., 1998). Several nit and NitM mutants from each isolate were selected for complementation tests. No selfincompatibility was observed between complementary nit
Table 1. Recovery of nitrate non-utilizing (Nit) mutant from 44 isolates of Pyrenophora graminea obtained in this study ${ }^{\mathrm{a}}$

\begin{tabular}{|c|c|c|c|c|c|}
\hline \multirow{2}{*}{\multicolumn{2}{|c|}{ VCG }} & \multirow{2}{*}{$\begin{array}{l}\text { Number of } \\
\text { mutants }\end{array}$} & \multicolumn{3}{|c|}{ Phenotypes of nit mutants } \\
\hline & & & nit mutants & \multicolumn{2}{|c|}{ NitM } \\
\hline \multicolumn{2}{|c|}{$1-\mathrm{A}$} & 44 & 20 & \multicolumn{2}{|c|}{24} \\
\hline \multicolumn{2}{|c|}{$1-B$} & 16 & 15 & \multicolumn{2}{|c|}{1} \\
\hline \multicolumn{2}{|c|}{$1-\mathrm{C}$} & 33 & 15 & \multicolumn{2}{|c|}{18} \\
\hline \multicolumn{2}{|c|}{ Total } & 93 & $50(53.76 \%)$ & \multicolumn{2}{|c|}{$43(46.24 \%)$} \\
\hline \multicolumn{6}{|c|}{$\begin{array}{l}{ }^{a} \text { Nit mutants were generated using technique described by Puhalla } \\
(1985) \text {. }\end{array}$} \\
\hline \multicolumn{6}{|c|}{$\begin{array}{l}\text { Table 2. Geographic origin and number of isolates belonging to } \\
\text { each vegetative compatibility groups of Pyrenophora graminea }\end{array}$} \\
\hline & \multicolumn{5}{|c|}{ Number of isolates within each VCG } \\
\hline VCG & ICARDA $^{\mathrm{a}}$ & $\begin{array}{l}\text { Daraa } \\
\text { (south) }\end{array}$ & $\begin{array}{cr}\text { Aleppo } & \mathrm{Hc} \\
\text { (north) } & \text { (nor }\end{array}$ & $\begin{array}{l}\text { ake } \\
\text {-east) }\end{array}$ & Total \\
\hline $1-\mathrm{A}$ & 3 & 3 & 10 & 8 & 24 \\
\hline $1-\mathrm{B}$ & 7 & 4 & 3 & 1 & 15 \\
\hline $1-\mathrm{C}$ & 3 & 1 & 1 & - & 5 \\
\hline Total & 13 & 8 & 14 & 9 & 44 \\
\hline
\end{tabular}

Table 3. Disease severity of Pyrenophora graminea isolates belonged to different vegetative compatibility groups

\begin{tabular}{lcl}
\hline \hline & \multicolumn{2}{c}{ Disease severity } \\
\cline { 2 - 3 } VCG & Incidence $(\%)^{\mathrm{a}}$ & Disease development \\
\hline $1-\mathrm{A}$ & $90.1 \mathrm{a}(78.3-100)$ & Up to flag leaf $(90 \%)$ \\
$1-\mathrm{B}$ & $21.0 \mathrm{c}(13.6-26.1)$ & First leaf $(20 \%)$ \\
$1-\mathrm{C}$ & $40.8 \mathrm{~b}(34.2-50.7)$ & Lower three leaves $(60 \%)$ \\
\hline
\end{tabular}

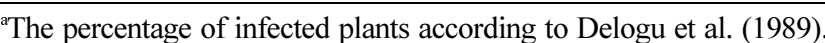
Means followed by different letters are significantly different using the Newman-Keuls test $(P=0.05)$. The number in the parentheses indicates the ranges of pathogenicity of isolate in each VCG.

mutants recovered from the same isolate of $P$. graminea.

Based on pairing complementary Nit mutants of all isolates, the 44 isolates were grouped into three VCGs. They consisted of one large VCG (24 isolates), arbitrarily designated as 1-A, and two other VCGs-1-B (15 isolates), and 1-C (5 isolates). VCG 1-A was widely distributed throughout the collection area (Table 2).

All 44 isolates caused disease symptoms on the barley genotype Arrivate, but the level of virulence of each isolate varied greatly. Disease incidence ranged from 13.6 to $100 \%$, and severity was up to flag leaves (90\%) in the VCG-1-A (Table 3). Moreover, mean incidence of isolates in VCG 1A was significantly $(P=0.05)$ higher than those of other VCGs (Table 3). These results suggest that VCG is associated with virulence in $P$. graminea. However, the virulent and weakly virulent isolates were not concentrated in one region of the country, this suggests that $P$. graminea 
isolates might be derived from the same founder source population and disseminated from one area to another in association with their hosts. This is highly plausible given that $P$. graminea has a wide host range, and is a seedborne pathogen (Mathre, 1990).

A similar relationship has been reported in Verticillium dahliae Kleb. (Cherrab et al., 2002), in Colletotrichum coccodes (Nitzan et al., 2006), and in Cochliobolus sativus (Arabi and Jawhar, 2007). Furthermore, strong virulence of isolates in VCG 1-A (mean disease incidence 90.1\%; and severity up to flag leaf) may explain why this group was predominant in our collection from barley showing disease symptoms in the field.

Our results showed that there was a significant variation in the virulence of $P$. graminea among VCGs isolates (Table 3). These differences may have practical importance, especially in new plantations where soil assays for $P$. graminea estimate the population level without differentiating among VCGs. Data on the VCG distribution of detected $P$. graminea populations, and on the relative virulence of each VCG, would enable a more accurate evaluation of potential damage and the control measures. Determination of potential virulence to barley in P. graminea populations is also important for accurate selection of isolates when screening resistant and tolerant barley lines in breeding programs.

In this study, three VCGs of $P$. graminea were recovered in Syria. VCG 1-A was the most common group within growing regions and proved to be the most virulent of the VCGs identified. These data indicate that the level of virulence in $P$. graminea is related to VCG. Therefore, it may be useful to monitor the outbreak of VCG 1-A in the replanted fields for the successful control of leaf stripe disease and to screen breeding lines of barley. To our knowledge, this is the first report of the classification of $P$. graminea obtained from barley into VCGs.

\section{Acknowledgments}

The authors thank the Director General of AECS and the Head of the Molecular Biology and Biotechnology Department for their support.

\section{References}

Ahn, I. P., Chung, H. S. and Lee, Y. H. 1998. Vegetative compatibility groups and pathogenicity among isolates of Fusarium oxysporum f. sp. cucumerinum. Plant Dis. 82:244-246.

Anonymous, 1988. STAT-ITCF, Programme, MICROSTA, realized by ECOSOFT, $2^{\text {nd }}$ Ver. Institut Technique des Cereals et des Fourrages Paris, France.

Arabi, M. I. E., Jawhar, M., Al-Safadi, B. and MirAli, N. 2004. Yield responses of barley to leaf stripe (Pyrenophora graminea) under experimental conditions in southern Syria. J. Phytopathol. 152:519-523.

Arabi, M. I. E., Jawhar, M. and MirAli, N. 2005. Storage protein (hordein) patterns of barley-Pyrenophora graminea interaction. Seed Sci. Tech. 33:409-418.

Arabi, M. I. E., Jawhar, M. and MirAli, N. 2006. Polypeptide patterns of Syrian isolates of Pyrenophora graminea. J. Plant Pathol. 88:129-132.

Arabi, M. I. E. and Jawhar, M. 2007. Vegetative compatibility and pathogenicity in Cochliobolus sativus. Aust. Plant Pathol. 36:173-174.

Cherrab, M., Bennani, A., Charest, P.M. and Serrhini, M.N. 2002. Pathogenicity and vegetative compatibility of Verticillium dahliae Kleb. isolates from olive in Morocco. J. Phytopathol. 150:703-709.

Correl, J. C., Klittich, C. J. R. and Leslie, J. F. 1987. Nitrate nonutilizaing mutants of Fusarium oxysporum and their use in vegetative compatibility tests. Phytopathology 77:1640-1646.

Day, P. R. 1974. Genetics and host-parasite interaction. W.H. Freeman and Company, San Francisco, CA, USA.

Gatti, A., Rizza, F., Delogu, G., Terzi, V., Porta-Puglia, A. and Vannacci, G. 1992. Physiological and biochemical variability in a population of Drechslera graminea. J. Genet. Breed. 46:179-186.

Grubisha, L. C. and Cotty, P. J. 2010. Genetic isolation among sympatric vegetative compatibility groups of the aflatoxinproducing fungus Aspergillus flavus. Mol. Ecol. 19:269-280.

Hammouda, A. M. 1986. Modified technique for inoculation in leaf stripe of barley. Acta Phytopathol. Entomol. Hung. 21: 255-259.

Jacobson, D. J. and Gordon, T. R. 1988. Vegetative compatibility and self incompatibility within Fusarium oxysporum f. sp. melonis. Phytopathology 78:668-672.

Jawhar, M., Sangawn, R. S. and Arabi, M. I. E. 2000. Identification of Drechslera graminea isolates by cultural characters and RAPD analysis. Cereal Res. Comm. 28:89-93.

Leslie, F. J. 1993. Fungal vegetative compatibility. Annu. Rev. Phytopathol. 31:127-150.

Larkin, R. P., Hopkins, D. L. and Martin, F. N. 1990. Vegetative compatibility within Fusarium oxysporum f. sp. niveum and its relationship to virulence, aggressiveness, and race. Can. J. Microbiol. 36:352-358.

Kauserud, H. 2004. Widespread vegetative compatibility groups in the dry-rot fungus Serpula lacrymans. Mycologia 96:232239.

Korolev, N., Katan, J. and Katan, T. 2000. Vegetative compatibility groups of Verticillium dahlia in Israel: their distribution and association with pathogenicity. Phytopathology 90: 529-536.

Mathre, D. E. 1990. Compendium of Barley Disease, 2nd edn. Montana State University, Bozeman, Montana. St. Paul, Minnesota, USA. The American Phytopathological Society, 90 pp.

Nitzan, N., Hazanovsky, M., Tal, M. and Tsror, L. 2002. Vegetative compatibility groups in Colletotrichum coccodes, the causal agent of black dot on potato. Phytopathology 92:827832.

Nitzan, N., Tsror, L. and Johnson, D. A. 2006. Vegetative compat- 
ibility groups and aggressiveness of North American isolates of Colletotrichum coccodes, the causal agent of potato black dot. Plant Dis. 90:1287-1292.

Porta-Puglia, A., Delogu, G. and Vannacci, G. 1986. Pyrenophora graminea on winter barley seed: effect on disease incidence and yield losses. Phytopathology 117:26-33.

Puhalla, J. E. 1985. Classification of strains of Fusarium oxysporum on the basis of vegetative compatibility. Can. J. Bot. 63:179183.

Wasilwa, L. A., Correll, J. C., Morelock, T. E. and McNew, R. E. 1993. Reexamination of races of the cucurbit anthracnose pathogen Colletotrichum orbiculare. Phytopathology 83:1190-1198.

Zadoks, J. C., Chang, T. T. and Konzak, C. F. 1974. A decimal code for the growth stages of cereals. Weed Res. 14:415-421. 